\title{
PENGARUH EFEKTIVITAS MODERNISASI SISTEM ADMINISTRASI PERPAJAKAN, TINGKAT PEMAHAMAN PERATURAN PERPAJAKAN, DAN SANKSI PERPAJAKAN TERHADAP TINGKAT KEPATUHAN WAJIB PAJAK ORANG PRIBADI \\ ( Studi Survey dengan Wajib Pajak Orang Pribadi yang Terdaftar d Kantor Pelayanan Pajak Pratama Bekasi Barat)
}

\author{
Alwi Raninda Sari ${ }^{1}$ ) \\ 1) Mahasiswa Program Studi Akuntansi FE UNKRIS \\ Dewi Rejeki' ${ }^{2}$ \\ 2) Dosen Program Studi Akuntansi FE UNKRIS \\ Alamat: Kampus UNKRIS, Jatiwaringin Jakarta Timur \\ Email : dewi.and71@gmail.com
}

\begin{abstract}
This research aims to determine the compliance of individual taxpayers in the West Bekasi City Area, using several variables, such as the effectiveness of the modernization of the tax administration system, the level of understanding of tax regulations, and tax sanctions. The method used in this research is quantitative methods. Quantitative methods is a method that analyzes numbers or calculating primary data (questionnaires) obtained from the respondents. The results of this research prove that the variables, namely the effectiveness of the modernization of the tax administration system and the level of understanding of taxation regulations has a positive and significant effect, while for the tax sanctions variable it proves that there is no significant effect on taxpayer compliance in implementing taxation
\end{abstract}

Keywords : effectiveness of the modernization of the tax administration system, the level of understanding of tax regulations, tax sanctions and taxpayer compliance

\section{PENDAHULUAN}

Dalam setiap situasi dan kondisi perekonomian yang fluktuatif dan dinamis, pajak menjadi salah satu dari komponen tulang punggung keuangan perekonomian sebuah negara. Tidak hanya negara berkembang seperti Indonesia, hampir setiap negara menerapkan pemungutan pajak kepada seluruh rakyatnya demi kelangsungan hidup negara. Kontribusi Pajak di Indonesia sendiri semakin menjadi vital, pada laporan APBN setiap tahunnya sejak tahun 2015 hingga tahun 2019 mencatat penerimaan pajak selalu menjadi sumber utama pendapatan kas negara. Penerimaan pajak pada tahun 2019 tercatat sebesar 84,4\% atau Rp 1.332,06 Triliun. Berikut daftar target dan realisasi penerimaan pajak selama tahun 2019: 
Tabel 1. Perkembangan Target dan Realisasi Penerimaan Pajak Tahun 2019 ( Dalam Triliun 2019)

\begin{tabular}{lrrr}
\hline \multirow{2}{*}{ Indikator } & \multicolumn{1}{c}{$\begin{array}{c}\text { Target } \\
\text { RAPBN }\end{array}$} & Realisasi & Pencapaian \\
\cline { 2 - 4 } & \multicolumn{1}{c}{$(\mathbf{a})$} & \multicolumn{1}{c}{$(\mathbf{b})$} & $\mathbf{( b / a ~ x ~ 1 0 0 \% )}$ \\
\hline Pajak Penghasilan (PPh) & 894,45 & 770,29 & $86,12 \%$ \\
PPN \& PPnBM & 655,39 & 532,91 & $81,31 \%$ \\
PBB ( sektor P3 ) & 19,10 & 21,17 & $110,84 \%$ \\
Pajak Lain nya & 8,61 & 7,69 & $89,31 \%$ \\
\hline \multicolumn{1}{c}{ Total } & $\mathbf{1 . 5 7 7 , 5 5}$ & $\mathbf{1 . 3 3 2 , 0 6}$ & $\mathbf{8 4 , 4 4 \%}$ \\
\hline
\end{tabular}

Sumber : Laporan Kaledoskop APBN (2019)

Berdasarkan Tabel 1 diatas, pencapaian penerimaan pajak tahun 2019 tidak mencapai target sesuai APBN yaitu sebesar Rp 1.557,55 Triliun. Penyebab penerimaan pajak belum mencapai target yaitu, karena masih terjadinya pelemahan ekonomi baik global dan nasional kemudian berimbas pada penerimaan PPN Impor dan PPN Dalam Negeri, banyaknya pemberian insentif pajak, dan masih rendahnya tingkat kepatuhan wajib pajak baik dalam pembayaran dan pelaporan kewajiban perpajakannya. Ramli (2020)

Namun dari penyebab yang disebutkan di atas, faktor utama dari peningkatan penerimaan pajak adalah tingkat kepatuhan wajib pajak. Salah satu wilayah yang menurut Neilmaldrin Noor tingkat kepatuhan nya masih tergolong rendah adalah Jawa Barat. Pada wilayah Jawa Barat sendiri teracatat tingkat kepatuhan salah satu kantor wilayahnya masih minim yaitu Kanwil Jawa Barat III. Menurut Widosari selaku kepala Kanwil Jawa Barat III mengenai hal tersebut dikarenakan banyak daerah belum terjamah maksimal mengenai pengetahuan perpajakan, dan dalam praktik sosialisasi serta penagihan kepada wajib pajak juga terhambat. Bekasi Barat menjadi salah satu wilayah dari Kanwil Jawab Barat III. Berikut adalah daftar tingkat kepatuhan wajib pajak di KPP Pratama Bekasi Barat dari tahun 2016 hingga tahun 2019.

Tabel 1. Kepatuhan Wajib Pajak Tahun 2016-2019

\begin{tabular}{cccc}
\hline Tahun & WP Terdaftar & $\begin{array}{c}\text { WP Terdaftar } \\
\text { Wajib SPT }\end{array}$ & Realisasi SPT \\
\hline 2016 & 143.144 & 81.508 & 46.083 \\
2017 & 156.732 & 67.666 & 44.559 \\
2018 & 164.723 & 74.311 & 46.012 \\
2019 & 174.332 & 69.714 & 45.958 \\
\hline
\end{tabular}

Sumber : KPP Pratama Bekasi Barat (2020)

Berdasarkan Tabel 2 di atas, maka dapat terlihat dalam 4 tahun terakhir tingkat kepatuhan wajib pajak masih mengalami fluktuasi, dapat dilihat wajib pajak terdaftar wajib SPT dan realisasi SPT pada tahun 2018 mengalami kenaikan dibandingkan tahun 2017, namun pada 2019 kembali terjadi penurunan. Dengan adanya administrasi perpajakan dengan sistem modernisasi, pemahaman terhadap peraturan perpajakan yang berlaku, dan pengenaan sanksi perpajakan untuk para wajib pajak yang melanggar menjadikan kepatuhan wajib pajak mengalami peningkatan yang fluktiatif.

Direktorat Jenderal Pajak (DJP) telah membuat pembaruan sistem administrasi perpajakan self assasment menjadi lebih modern, memanfaatkan perkembangan teknologi This work is licensed under a Creative Commons Attribution-Nomercial-ShareAlike 4.0 International Licen Ciptaan disebarluaskan di bawah Lisensi Creative Commons Atribusi-BerbagiSerupa 4.0 Internasional.

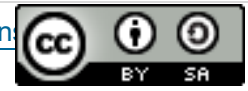


dan informasi di era yang serba digital dalam upaya meningkatkan kepatuhan pembayar pajak dan kualitas pelayanannya. Pengembangan sistem pelaporan pajak baik terutang ataupun lebih bayar dibuat dengan berbasis $e$-system, terdiri dari e-registation, e-spt, $e$ filling, e-billing. Hal tersebut bertujuan mempermudah para Wajib Pajak (WP) baik perorangan ataupun badan utnuk memenuhi kewajibannya dalam pembayaran dan pelaporan perpajakan. Bersamaan dari pembaharuan sistem perpajakan menjadi lebih modern, Direktorat Jenderal Pajak (DJP) berharap adanya kemudahan tersebut dapat berefek pada meningkatnya kepatuhan para wajib pajak. Hal tersebut sejalan dengan penelitian yang dilakukan oleh Putri (2019), bahwa wajib pajak akan sukarela melaksanakan kewajiban dalam perpajakannya jika sistem administrasi perpajakan mudah dan cepat.

Keterkaitan dalam pembaruan sistem perpajakan, DJP juga mengeluarkan kebijakan serta peraturan perpajakan baru guna mendampingi pelaksasaan modernisasi tersebut. Dalam hal ini, peran DJP yaitu memberikan sosialisasi secara rutin kepada para wajib pajak ketika terdapat pembaharuan peraturan, agar wajib pajak memahami peraturan perpajakan yang berlaku dengan baik dan benar, karena dengan adanya pemahaman mengenai peraturan perpajakan yang berlaku akan meminimalisir terjadinya kesalahan dalam memperoleh hak dan melaksanakan kewajiban dalam perpajakan.

Tingkat ketidakpatuhan para wajib pajak yang masih sangat tinggi membuat DJP mengambil langkah pemberian hukuman berupa sanksi perpajakan jika wajib pajak tidak melaksanakan kewajiban perpajakannya. Dalam penelitiannya, Rahmi (2018) menyatakan bahwa Efektivitas penerapan sanksi perpajakan berpengaruh positif dan signifikan terhadap tingkat kepatuhan pengusaha kena pajak yang akan mematuhi pelaporan dan pembayaran pajak jika memandang atau menilai sanksi denda yang diterima akan lebih merugikan pengusaha kena pajak tersebut.

Berdasarkan uraian latar belakang diatas, dapat dirumuskan permasalahan dalam penelitian ini sebagai berikut: 1). Bagaimana pengaruh Efektvitas Modernisasi Sistem Admnistrasi Perpajakan terhadap Tingkat Kepatuhan Wajib Pajak Orang Pribadi ?. 2). Bagaumana pengaruh Tingkat Pemahaman Peraturan Perpajakan terhadap Tingkat Kepatuhan Wajib Pajak Orang Pribadi ?. 3). Bagaimana pengaruh Pengenaan Sanksi Perpajakan terhadap Tingkat Kepatuhan Wajib Pajak Orang Pribadi ?. 4). Bagaimana Pengaruh Efektivitas Modernisasi Sistem Perpajakan Tingkat Pemahaman Peraturan Perpajakan, dan Sanksi Perpajakan secara simultan terhadap Tingkat Kepatuhan Wajib Pajak Orang Pribadi ?

\section{LANDASAN TEORI}

\section{Pajak dan Wajib Pajak}

Pajak berdasarkan UU KUP No.28 Tahun 2007 ayat 1 dalam pasal 1 yaitu kontribusi wajib kepada negara yang terutang oleh orang pribadi atau badan yang bersifat memaksa berdasarkan Undang-Undang, dengan tidak mendapatkan hasil kembali secara langsung dan digunakan untuk keperluan negara bagi sebesar besarnya kemakmuran rakyat. Menurut Mardiasmo M (2016) tentang pajak : "Pajak merupakan kontribusi rakyat kepada kas negara yang berdasarkan undang-undang (yang dipaksakan) dengan tiada mendapat jasa timbal balik (kontraprestasi) secara langsung dapat ditunjukan dan yang digunakan untuk membayar pengeluaran umum"

Terdapat 2 fungsi pajak yang dijelaskan oleh (Mardiasmo, 2016), fungsi anggaran (Budgetair), dimana pajak berfungsi sebagai salah satu sumber dana bagi pemerintah untuk membiayai pengeluaran-pengeluarannya; (2) fungsi mengatur (Regulered), dimana pajak 
mempunya fungsi menjadi salah satu alat untuk mengatur atau melaksanakan kebijaksanaan pemerintah dalam bidang sosial serta ekonomi.

Menurut Wardoyo (2017) secara umum pajak yang diberlakukan didalam Indonesia dapat dibedakan menurut : (1) Sifatnya, yaitu pajak langsung dan tidak langsung; Sasaran/Objeknya, yaitu pajak subjektif dan pajak objektif; (3) Pemungutnya, yaitu pajak pusat dan pajak daerah.

Mardiasmo (2016) mengatakan bahwa sistem pemungutan pajak dapat terbagi menjadi 3 (tiga), yaitu : (1) Official Assesment System, yaitu metode pemungutan yang memberi wewenang kepada pemerintah sebagai fiskus untuk menentukan besaran pajak terutang oleh wajib pajak; (2) Self Asssesemnet System ialah metode pemungutan pajak dengan memberi wewenang pada wajib pajak untuk menentukan besaran pajak terutangnya; (3) Withholding System, yaitu metode pemungutan pajak yang diberikan kepada pihak ketiga selain fiskus dan wajib pajak itu sendiri, untuk memotong atau memungut pajak terutangnya.

Dalam perhitungan besaran pajak terutang, didasarkan dengan 2 (dua) unsur yaitu dasar pengenaan pajak dan tarif pajak. Dasar Pengenaan Pajak/DPP merupakan dasar nilai dalam menghitung pajak yang terutang, sementara menurut Waluyo (2016) Dasar Pengenaan Pajak/DPP merupakan total dari harga jual atau penggantian nilai impor atau nilai ekspor yang sesuai penetapan Keputusan Menteri Keuangan yang dipakai sebagai dasar perhitungan pajak yang terutang. Dan tarif pajak merupakan angka atau persentase tertentu yang akan dihitung sesuai DPPnya. Berdasarkan jenisnya tarif dibedakan menjadi tarif tetap, tarif proposional (sebanding), tarif progresif (meningkat), dan tarif degresif (menurun).

Secara umum Wajib Pajak adalah pihak yang memiliki kewajiban perpajakan. Namun menurut Sari (2013) menyatakan bahwa pengertian dari Wajib Pajak adalah pihak dalam ketentuan undang-undang perpajakan yang ditunjuk untuk menjalankan kewajiban perpajakan. Sedangkan dalam KUP No.28 Ayat 2 dalam pasal 1 Tahun 2007 tentang wajib pajak adalah orang pribadi atau badan, meliputi pembayar pajak, pemotong pajak, dan pemungut pajak, yang mempunyai hak dan kewajiban perpajakan sesuai dengan ketentuan peraturan perundang-undangan perpajakan. Wajib Pajak sendiri terbagi menjadi 2 yaitu Wajib Pajak Orang Pribadi (WPOP) dan Wajib Pajak Badan (WPB).

\section{Efektivitas Modernisasi Sistem Administrasi Perpajakan}

Dalam penelitian Nik Amah (2020), efektivitas merupakan kaitan antara apa yang direncanakan, proses kegiatan dan keluaran dengan tujuan atau sasaran yang harus dicapai. Kegiatan dikatakan efektif apabila proses kegiatan mencapai tujuan dan sasaran akhir kebijakan (spending wisely).

Salah satu reformasi perpajakan di Indonesia berawal dari perubahan sistem dari official assessment system menjadi self assessment, dimana wajib pajak diberikan kebebasan untuk menghitung, membayar dan melaporkan sendiri kewajiban perpajakannya dan mengurangi upaya kontak langsung antara Wajib Pajak dengan petugas yang pada sebelumnya banyak terjadi praktek ilegal dalam masalah besarnya terutang pajak para Wajib Pajak. Setelah reformasi mengenai sistem pemungutan, dalam penelitian Farah Latifah Nurfauziah (2017), DJP melakukan modernisasi sistem perpajakan. Hal ini merupakan langkah DJP yang menerapkan sistem administrasi perpajakan lebih transparan dan akuntabel (good governance), dengan memanfaatkan sistem informasi teknologi yang handal dan terkini.

Upaya modernisasi tersebut diwujudkan melalui optimalisasi penggunaan teknologi komunikasi dan informasi yang mengarah kepada otomasi lengkap (full automation) guna menunjang dan mempercepat kegiatan para wajib pajak dalam memenuhi hak dan This work is licensed under a Creative Commons Attribution-Nomercial-ShareAlike 4.0 International Licen (CC) (P) (e) 
kewajiban perpajakan nya. Diantaranya dengan dibukanya fasilitas berupa : (1) Situs internet Dirjen Pajak (http:///www.pajak.go.id) yang memuat aturan dan informasi perpajakan; (2) Sistem e-Billing, sistem pembuatan Surat Setoran Elektronik dengan kode billing untuk pembayaran atau penyetoran para untuk para Wajib Pajak pada negara; (3) Sistem $e$ registation ( $(e-R e g$ ), sistem pendaftaran wajib Pajak untuk memperoleh NPWP secara online; (4) Sistem e-Filling, sistem penyampaian (pelaporan) Surat Pemberitahuan Pajak (SPT) secara online; (5) Sistem program $e$-SPT yang merupakan sarana bagi wajib pajak untuk dapat menyampaikan SPT melalui media elektronik.

Dengan penjelasan diatas maka secara umum efektivitas modernisasi sistem administrasi perpajakan merupakan salah satu upaya DJP dalam menyesuaikan sarana dan prasarana sistem perpajakan dengan perkembangan sistem informasi yang handal dan terkini pada para wajib pajak. Dengan modernisasi sistem administrasi perpajakan diharapkan merupakan salah satu upaya dalam menaikan angka kepatuhan Wajib Pajak dalam memenuhi kewajiban perpajakannya. Namun pada kenyataan dilapangan pelaporan SPT para Wajib Pajak sampai saat ini tidak sebanding besarannya dengan data pendaftaran Wajib Pajak yang tercatat.

Adapun tujuan dari modernisasi sistem administrasi perpajakan menurut Sari (2013) adalah : (1) Tercapainya tingkat kepatuhan yang tinggi para Wajib Pajak; (2) Tercapainya tingkat kepercayaan yang tinggi para Wajib Pajak terhadap sistem perpajakan; Tercapainya tingkat produktivitas yang lebih tinggi dalam kinerja para pegawai pajak. Sedangkan Dimensi Modernisasi Sistem Administrasi Perpajakan dalam hasil penelitiannya Misra dan Fasmi (2014) menyatakan dalam Keputusan Menteri Keuangan Nomor 85/KMK 03/2003 tentang Modernisasi Sistem Administrasi Perpajakan meliputi 4 dimensi yaitu : (1) Susunan Organisasi ; (2) Prosedur Organisasi; (3) Skema Organisasi; Budaya Organisasi.

\section{Pemahaman Peraturan Perpajakan}

Pemahaman dalam Kamus Besar Bahasa dapat diartikan sebagai proses, cara, perbuatan memahami atau memahamkan, sedangkan secara umum pemahaman adalah hal yang sudah dimengerti secara mendalam. Pemahaman dalam peraturan perpajakan sendiri adalah diantara satu aspek penting untuk para wajib pajak dalam melaksanakan hak dan kewajiban perpajakannya. Sehingga tingkat pemahaman peraturan perpajakan adalah proses wajib pajak dalam mengerti dan memahami segala hal terkait peraturan perpajakan secara benar dalam melakukan hak dan kewajiban perpajakannya.

Wajib Pajak dapat dikatakan paham dan mengerti mengenai peraturan perpajakan apabila : (1) para Wajib Pajak mengetahui tentang apa saja kewajiban serta hak perpajakannya; (2) para Wajib Pajak mengetahui berapa besaran tarif pajak yang menjadi kewajiban perpajakannya; (3) para Wajib Pajak mengetahui bagaimana tata cara mengisi hingga proses dimana Surat Pemberitahuan Pajak (SPT) akan dilaporkan; (4) para Wajib Pajak mengetahui resiko (konsekuensi) apabila melanggar peraturan hak dan kewajiban perpajakannya sesuai undang-undang.

\section{Sanksi Perpajakan}

Sanksi Perpajakan dalam penjelasan menurut Mardiasmo (2018) ialah pertanggungjawaban bahwa undan-undang perpajakan akan dituruti/ditaati/dipatuhi, dengan kata lain sanksi perpajakan adalah alat pencegahan (preventif) agar para Wajib Pajak tidak melanggar norma perpajakan.

Dalam Undang-Undang Perpajakan Tahun 2009 No.16 tentang Ketentuan Umum dan Tata Cara Perpajakan, dikenal dengan dua macam sanksi, yaitu sanksi administrasi dan

This work is licensed under a Creative Commons Attribution-Nomercial-ShareAlike 4.0 International Licen Ciptaan disebarluaskan di bawah Lisensi Creative Commons Atribusi-BerbagiSerupa 4.0 Internasional. 
sanksi pidana. Pelanggaran suatu norma perpajakan pemberian tidak dengan sanksi administrasi saja, namun ada pula dengan sanksi pidana saja, dan ada pula yang dengan sanksi administrasi dan sanksi pidana. Adapun penjelasan tentang Sanksi Administrasi \& Sanksi pidana berlandaskan UU KUP 2007 : (1) Sanksi administrasi adalah pembayaran kerugian kepada negara, khususnya yang berupa denda, bunga dan kenaikan;

Sanksi pidana ialah hukuman dan merupakan suatu alat terakhir atau tameng hukum para fiskus agar norma perpajakan dipatuhi. Dalam penjelasan Mardiasmo (2018) Sanksi pidana dapat berupa denda pidana, kurungan dan penjara denda pidana. Sedangkan sanksi denda administrasi yang hanya diancam/dikenakan kepada Wajib Pajak yang melanggar ketentuan peraturan perpajakan, sanksi berupa denda pidana selain dikenakan kepada Wajib Pajak ada juga yang diancam kepada pejabat pajak tau kepada pihak ketiga yang melanggar norma. Denda pidana dikenakan kepada tindak pidana yang bersifat pelanggaran maupun bersifat kejahatan.

\section{Kepatuhan Wajib Pajak}

Saat ini dalam sistem pemungutannya Indonesia menerapkan self assessment system dimana segala pemenuhan kewajiban perpajakan dilakukan sepenuhnya oleh wajib pajak, dimana kepatuhan wajib pajak menjadi hal utama dalam proses jalannya sistem self assesment. Menurut Supadmi (2016), kepatuhan wajib pajak adalah perilaku dari seorang wajib pajak dalam melakukan semua kewajiban perpajakan dan menggunakan hak perpajakannya dengan tetap berpatokan kepada peraturan perundang-undangan perpajakan.

Pengertian kepatuhan wajib pajak menurut Pandiangan (2014) adalah kepatuhan melaksanakan kewajiban perpajakan yang merupakan salah satu ukuran kinerja wajib pajak di bawah pengawasan Direktorat Jenderal Pajak (DJP). Dalam artian, tinggi rendahnya kepatuhan wajib pajak dapat dijadikan pertimbangan DJP dalam melakukan pembinaan, pengawasan, pengelolaan, dan tindak lanjut terhadap wajib pajak (WP), misalnya apakah akan dilakukan himbauan atau konseling atau penelitian atau pemeriksaan dan lainnya seperti penyidikan terhadap Wajib Pajak. Dalam KBBI Rahayu (2010), istilah kepatuhan diartikan dengan tunduk, patuh pada aturan. Dalam perpajakan kita dapat memberi pengertian bahwa kepatuhan perpajakan merupakan ketaatan, tunduk, dan patuh serta melaksanakan ketentuan perpajakan.

Wajib pajak yang patuh merupakan wajib pajak yang taat dan memenuhi serta melaksanakan kewajiban perpajakan sesuai dengan ketentuan undang-undangan perpajakan. Aturan Kementrian Keuangan dalam 544/KMK.04/2000 menjelaskan tentang kepatuhan wajib pajak, yaitu : (1) dalam penyampaian SPT tepat waktu untuk semua jenis pajak dalam jangka waktu 2 tahun terkahir; (2) dalam penyampaian SPT Masa (perbulan) tidak terlambat lebih dari 3 (tiga) masa pajak dan dengan terlambat beruturut-turut dalam tahun berjalan untuk setiap jenis pajak; (3) dalam penyampaian SPT Masa yang terlambat seperti pada poin ke-2, yang telah disampaikan tidak boleh lebih dari jatuh tempo tanggal penyampaian spt masa pajak berikutnya;

(4) tidak memiliki tunggakan pajak (pajak terutang belum terbayarkan) untuk semua jenis pajak; (5) tidak memiliki jejak dijatuhi dalam tindak pindana pajak dalam kurun waktu 10 tahun terkahir; (6) laporan keuangan yang diaudit oleh akuntan publik, BPK, dan pembangunan dapat dijalankan dengan pendapat wajar tanpa pengecualian. Laporan audit disusun dengan bentuk panjang serta adanya laba rugi komersial dan fiskal; (7) pada laporan keuangan yang tidak diaudit oleh akuntan publik, maka wajib pajak bisa mengadakan ajuan permohonan untuk ditetapkan sebagai wajib pajak dengan kriteria tertentu sesuai dengan syarat dalam UU No.16 tahun 2009. 


\section{METODE PENELITIAN}

Populasi yang digunakan penelitian ini adalah para Wajib Pajak Orang Pribadi yang Terdaftar di Kantor Pelayanan Pajak Pratama Bekasi Barat hingga tahun 2019 sebanyak 164.078 Sedangkan sample digunakan dalam penelitian ialah Random sampling yaitu proses penyampelan dengan cara acak, dengan artian setiap subjek mempuanyai peluang untuk dijadikan sampel Chandrarin (2017).

Metode yang digunakan dalam menentukan sample dengan menggunakan rumus slovin, yaitu :

$$
\begin{aligned}
\mathrm{n} \quad & =\frac{164.078}{1+164.078(0,1)^{2}} \\
& =99,93909(\text { dibulatkan menjadi } 100)
\end{aligned}
$$

Penelitian ini menggunakan metode pengumpulan data dengan menyebarkan kuisioner kepada para responden Wajib Pajak Orang Pribadi KPP Pratama Bekasi Barat. Teknis analisis data yang digunakan adalah analisis statistic deskritif, analisis regresi linier berganda dengan rumus persamaannya sebagai berikut :

$$
\mathrm{Y}=\mathrm{a}+\mathrm{b} 1 \mathrm{X} 1+\mathrm{b} 2 \mathrm{X} 2+\mathrm{b} 3 \mathrm{X} 3+\mathrm{e}
$$

Keterangan :

$\mathrm{Y}=$ Kepatuhan Wajib Pajak yang Terdaftar di Kantor Pelayanan

Pajak Pratama Bekasi Barat

$\mathrm{a}=$ Bilangan Konstanta

$\mathrm{b}=$ Koefisien Regresi

$\mathrm{X} 1=$ Modernisasi Sistem Administrasi Perpajakan

$\mathrm{X} 2$ = Pemahaman Peraturan Perpajakan

$\mathrm{X} 3$ = Sanksi Perpajakan

e $=$ Tingkat Kesalahan

\section{HASIL DAN PEMBAHASAN}




\section{Analisis Statistik Deskriptif}

Tabel 3. Hasil Uji Analisis Statistik Deskriptif

\begin{tabular}{lccccc}
\hline & N & Min. & Max. & Mean & $\begin{array}{c}\text { Std. } \\
\text { Deviation }\end{array}$ \\
\hline $\begin{array}{l}\text { Modernisasi Sistem } \\
\begin{array}{l}\text { Administrasi } \\
\text { Perpajakan }\end{array}\end{array}$ & 100 & 19 & 35 & 29,48 & 3,762 \\
\hline $\begin{array}{l}\text { Pemahaman } \\
\text { Peraturan Perpajakan }\end{array}$ & 100 & 16 & 30 & 24,61 & 3,615 \\
\hline Sanksi Perpajakan & 100 & 11 & 30 & 24,93 & 3,988 \\
\hline $\begin{array}{l}\text { Kepatuhan } \\
\text { Wajib Pajak }\end{array}$ & 100 & 15 & 30 & 26,73 & 3,706 \\
\hline Valid N (listwise) & 100 & & & & \\
\hline Sumber : Output SPSS Versi 25 & & & &
\end{tabular}

\section{Hasil Penelitian}

\section{Analisis Regresi Linear Berganda}

Tabel 4: Pengaruh Modernisasi Sistem Administrasi Perpajakan, Pemahaman Peraturan Perpajakan dan Sanksi Perpajakan Terhadap Kepatuhan Wajib Pajak

\section{Parameter}

\begin{tabular}{|c|c|c|c|c|c|c|}
\hline Variabel & Mult. R & R Square & Konstanta & $\begin{array}{c}\text { Koefisien } \\
\text { Regresi }\end{array}$ & Sig & $\alpha$ \\
\hline Modernisasi & & & & 0,248 & 0,008 & \\
\hline \multicolumn{7}{|l|}{ Sistem } \\
\hline \multicolumn{7}{|l|}{ Administrasi } \\
\hline Perpajakan & 0,713 & 0,509 & 5,544 & & & 0,05 \\
\hline Pemahaman & & & & 0,410 & 0,001 & \\
\hline \multicolumn{7}{|l|}{ Peraturan } \\
\hline \multicolumn{7}{|l|}{ Perpajakan } \\
\hline Sanksi & & & & 0,152 & 0,102 & \\
\hline \multicolumn{7}{|l|}{ Perpajakan } \\
\hline \multicolumn{7}{|c|}{ Pengujian Signifikan } \\
\hline $\mathrm{F}$ hitung $>\mathrm{F}$ & $\mathrm{el}=33,1$ & 3,14 & & & & \\
\hline
\end{tabular}

Berdasarkan hasil perhitungan uji $\mathrm{F}$ nilai $\mathrm{F}_{\text {hitung }}$ sebesar 33,172 dengan probabilitas signifikasi sebesar 0,000. Maka dapat artikan bahwa efektivitas modernisasi sistem administrasi perpajakan, tingkat pemahaman peraturan perpajakan, dan sanksi perpajakan secara bersama-sama berpengaruh positif dan signifikan terhadap kepatuhan wajib pajak orang pribadi. Nilai koefisien determinasi sebesar 0,509, artinya konstribusi yang diberikan variabel efektivitas modernisasi sistem administrasi perpajakan, pemahaman peraturan perpajakan dan sanksi perpajakan sebesar 50,9\% kepada kepatuhan wajib pajak orang pribadi, sedangkan sisanya sebesar $49,1 \%$ disumbangkan faktor lain yang tidak dibahas dalam penelitian ini. 
Berdasarkan persamaan regresi yang terbentuk dari pengujian regresi linear berganda, yaitu :

$$
\mathrm{Y}=5,544+0,248 \mathrm{X} 1+0,410 \mathrm{X} 2+0,152 \mathrm{X} 3+\mathrm{e}
$$

Efektivitas modernisasi sistem administrasi perpajakan, pemahaman peraturan perpajakan dan sanksi perpajakan berpengaruh signifikan terhadap kepatuhan wajib pajak orang pribadi pada tingkat nyata $99 \%$. Koefisien efektivitas modernisasi sistem administrasi perpajakan sebesar 0,248 artinya jika ada peningkatan efektivitas modernisasi sistem administrasi perpajakan, maka kepatuhan wajib pajak orang pribadi akan meningkat dengan asumsi pemahaman peraturan perpajakan dan sanksi perpajakan tidak berubah. Koefisien pemahaman peraturan perpajakan sebesar 0,410 , artinya jika ada peningkatan pemahaman peraturan perpajakan, maka kepatuhan wajib pajak orang pribadi akan meningkat dengan asumsi efektivtas modernisasi sistem administrasi perpajakan dan sanksi perpajakan tidak berubah, Koefisien sanksi perpajakan sebesar 0,152 , artinya jika ada perubahan sanksi perpajakan, maka kepatuhan wajib pajak orang pribadi akan meningkat dengan asumsi efektivitas modernisasi sistem administrasi perpajakan dan pemahaman peraturan perpajakan orang pribadi tidak berubah.

\section{Pembahasan Hasil Penelitian}

1. Pengaruh efektivitas modernisasi sistem administrasi perpajakan terhadap kepatuhan wajib pajak orang pribadi. Maka dapat disimpulkan efektivitas modernisasi sistem administrasi perpajakan berpengaruh positif siginifikan terhadap kepatuhan wajib pajak orang pribadi. Modernisasi sistem administrasi perpajakan merupakan salah satu bentuk reformasi perpajakan dari self assasment. Efektivitas dari pembaharuan sistem perpajakan yang lebih modern tersebut adalah memberikan kemudahan para wajib pajak terutama wajib pajak orang pribadi dan akan berdampak pada meningkatnya kepatuhan wajib pajak. Hasil penelitian ini sejalan dengan Kurniawan (2018) ) yang menyebutkan modernisasi sistem administrasi perpajakan berpengaruh positif terhadap kepatuhan wajib pajak orang pribadi diwilayah KPP Pratama Magelang. Dan menjelaskan semakin baik penerapan modernisasi administrasi perpajakan dalam pemenuhan kebutuhan perpajakan menggunakan pemanfaatan teknologi informasi maka akan memudahkan penyelesaian kewajiban perpajakan.

2. Pengaruh tingkat pemahaman peraturan perpajakan terhadap kepatuhan wajib pajak orang pribadi. Dari pengujian yang telah dilakukan oleh penelitian ini, maka dapat disimpulkan kaitan tingkat pemahaman peraturan perpajakan berpengaruh positif dan signifikan terhadap kepatuhan wajib pajak orang pribadi. Pemahaman peraturan perpajakan adalah kewajiban setiap para wajib pajak, atas peraturan yang berlaku. Hal tersebut dilakukan dengan sosialisasi oleh DJP untuk meminimalisir terjadinya kesalahan para wajib pajak khususnya orang pribadi dalam melaksanakan hak dan kewajiban perpajakan. Hasil penelitian ini sejalan dengan penelitian Inas Shofia Widiyati (2019) menjelaskan bahwa pemahaman pajak mempunyai pengaruh yang positif dan signifikan terhadap kepatuhan pembayaran pajak dengan sistem online e-SPTPD, hal tersebut mendiskripsikan bahwasanya pemahaman dalam suatu peraturan perpajakan yang berlaku mempunyai pengaruh dengan arah positif signifikan pada kepatuhan perpajakan.

3. Pengaruh sanksi perpajakan terhadap kepatuhan wajib pajak orang pribadi. Dari pengujian yang telah dilakukan oleh penelitian ini, maka dapat disimpulkan kaitan

This work is licensed under a Creative Commons Attribution-Nomercial-ShareAlike 4.0 International Licen Ciptaan disebarluaskan di bawah Lisensi Creative Commons Atribusi-BerbagiSerupa 4.0 Internasional. 
Sanksi Perpajakan tidak berpengaruh terhadap kepatuhan wajib pajak orang pribadi. Sanksi Perpajakan merupakan upaya dalam jaminan bahwa peraturan perundangundangan perpajakan (norma perpajakan) akan dituruti/ditaati/dipatuhi, dengan kata lain sanksi perpajakan merupakan akibat yang diberikan untuk para wajib pajak yang melanggar norma perpajakan. Hasil penelitian ini tidak sejalan dengan penelitian yang dilakukan Kurniawan (2018) yang menjelaskan penerapan sanksi administrasi perpajakan yang diberlakukan bagi wajib pajak dapat mempengaruhi kepatuhan wajib pajak, serta besar atau kecilnya sanksi yang diberikan petugas pajak berpengaruh terhadap kepatuhan wajib pajak.

4. Pengaruh efektivitas modernisasi sistem administrasi perpajakan, pemahaman peraturan perpajakan dan sanksi perpajakan terhadap tingkat kepatuhan wajib pajak orang pribadi, dapat disimpulkan bahwa kaitan variabel bebas (Independen) yaitu efektivitas modernisasi sistem administrasi perpajakan, tingkat pemahaman peraturan perpajakan, dan sanksi perpajakan secara bersama-sama berpengaruh secara positif dan signifikan terhadap kepatuhan wajib pajak orang pribadi. Hasil penelitian ini sejalan dengan penelitian yang dilakukan Supadmi (2016) Kepatuhan wajib pajak adalah perilaku dari seorang wajib pajak dalam melakukan semua kewajiban perpajakan dan menggunakan hak perpajakannya dengan tetap berpatokan kepada peraturan perundang-undangan perpajakan. Adanya sarana yang mendukung seperti modernisasi sistem administrasi perpajakan yang membuat perpajakan lebih efektif, pemahaman peraturan para wajib ajak, dan dengan adanya sanksi perpajakan yang dikenakan pada wajib pajak yang melanggar akan membuat perubahan dimasa datang untuk tidak melanggarnya kembali.

\section{KESIMPULAN \& REKOMENDASI}

\section{Kesimpulan}

1. Efektivitas Modernisasi Sistem Administrasi Perpajakan berpengaruh secara positif dan signifikan terhadap Tingkat Kepatuhan Wajib Pajak Orang Pribadi. Berdasarkan hasil penelitian menunjukan bahwa adanya modernisasi sistem administrasi dalam bidang perpajakan sudah terbukti lebih efektif dan memudahkan para wajib pajak dalam memenuhi baik hak dan kewajiban perpajakan yang dimiliki. Karena hal tersebut membuat tingkat kepatuhan wajib pajak dapat juga semakin meningkat.

2. Tingkat Pemahaman Peraturan Perpajakan berpengaruh secara positif dan signifikan terhadap terhadap Tingkat Kepatuhan Wajib Pajak Orang Pribadi yang terdaftar pada Kantor Pelayanan Pajak Pratama Wilayah Bekasi Barat. Berdasarkan hasil penelitian menunjukan bahwa sebagian besar para wajib pajak sudah cukup paham peraturan perpajakan yang berlaku untuk menjalankan baik hak dan kewajiban perpajakan yang dimiliki. Karena hal tersebut membuat tingkat kepatuhan wajib pajak juga dapat semakin meningkat.

3. Sanksi Perpajakan tidak berpengaruh terhadap Tingkat Kepatuhan Wajib Pajak Orang Pribadi yang terdaftar pada Kantor Pelayanan Pajak Pratama Wilayah Bekasi Barat. Berdasarkan hasil penelitian menunjukan bahwa dalam hal ini sanksi perpajakan tidak mempengaruhi para wajib pajak, karena bagi mereka sanksi pajak yang diberikan belum cukup membuat jera untuk tidak mengulangi pelanggaran yang dilakukan serta beranggapan sanksi perpajakan hanya legalitas dalam peraturan, untuk tindakan tegas atas pelanggaran belum ditindak tegas secara adil dan menyeluruh oleh pemerintah. 
Karena hal tersebut tidak membuat tingkat kepatuhan wajib pajak juga dapat semakin meningkat.

4. Berdasarkan Efektivitas Modernisasi Sistem Administrasi Perpajakan, Tingkat Pemahaman Peraturan Perpajakan, dan Sanksi Perpajakan tidak secara besamaan variabel tersebut mempengaruhi Tingkat Kepatuhan Wajib Pajak Orang Pribadi yang terdaftar pada Kantor Pelayanan Pajak Pratama Wilayah Bekasi Barat.

\section{DAFTAR PUSTAKA}

Chandrarin, G. (2017). Metode Riset Akuntansi Pendekatan Kuantitatif. Jakarta: Salemba Empat.

Farah Latifah Nurfauziah, A. R. (2017). Modernisasi Administrasi Perpajakan Dan Kepatuhan Wajib. URNAL EKUBIS Volume 2 No. 1, 82-97.

Ghozali, I. (2016). Aplikasi Analisis Multivariate dengan Program IBM SPSS. Semarang: BPFE Universitas Diponegoro.

Gujarati, D. N. (2015). Dasar-Dasar Ekonometrika Edisi 5 Buku 2. Jakarta: Salemba Empat. Harjo, D. (2019). Perpajakan Indonesia Edisi 2. Bogor: Mitra Wacana Media.

Hatmawan, S. R. (2020). Metode Riset Penelitian Kuantitatif. Yogyakarta: CV.Budi Utama. Herlina. (2019). Panduan Praktis Mengelola Kuesioner dengan SPSS. Jakarta: PT Elex. Media Komputiondo.

https://kbbi.web.id/paham. (t.thn.).

Inas Shofia Widiyati, F. (2019). Pengaruh Pemahaman, Kesadaran, Sosialisasi, Dan Sanksi Terhadap Kepatuhan Penggunaan Pembayaran Pajak Dengan Online System Oleh Wajib Pajak Hotel Dan Restoran Di Daerah Kota Yogyakarta. Journal of Management \& Business Vol 2 No 2 , 24-37.

Intan Kartika Wulandara, A. (2020). Pengaruh Modernisasi Sistem Administrasi Perpajakan Dan Efektivitas Sistem Perpajakan Terhadap Kepatuhan Wajib Pajak Orang Pribadi Kpp Pratama Banda Aceh. Jurnal Ilmiah Mahasiswa Ekonomi Akuntansi (JIMEKA), $1-12$.

Kurniawan, I. (2018). Pengaruh Modernisasi Sistem Administrasi Perpajakan, Sanksi Perpajakan Terhadap Kepatuhan Wajib Pajak Orang Pribadi (Studi Kasus pada Kantor Pelayanan Pajak Pratama Magelang). Jurnal Ekobis Dewantara Vol. 1 No. 3, 1-11.

Mardiasmo. (2018). Perpajakan Indonesia . Yogyakarta: Andi.

Mardiasmo, M. (2016). Perpajakan. Yogyakarta: Penerbit ANDI.

Misra, L. F. (2014). Modernisasi Sistem Administrasi Perpajakan Dan Tingkat Kepatuhan Pengusaha Kena Pajak. Dalam D. S. Monica Angelina Tandiyo, Jurnal Akuntansi Multiparadigma (hal. 76-87). Malang: Universitas Brawijaya.

Nelly Prima Putri, A. T. (2019). Pengaruh Sistem Administrasi Perpajakan Modern,Akuntabilitas Dan Sanksi Perpajakan Terhada. Jurnal Benefita 4, 386-398.

Nik Amah, J. A. (2020). Efektivitas Modernisasi Administrasi Pajak Dan Kepatuhan Pajak. Seminar Nasional Hasil Penelitian dan Pengabdian kepada Masyarakat UNIPMA, 327-335.

Nuraenah. (2016). Pengaruh Modernisasi Sistem Administrasi Perpajakan Terhadap Kepatuhan Wajib Pajak. Skripsi.

Pandiangan, L. (2014). Administrasi Perpajakan. Jakarta: Erlangga.

Rahayu, S. K. (2017). Perpajakan (Konsep dsn Aspek Formal). Bandung: Rekayasa Bisnis. 
Rahmi, D. A. (2018). Pengaruh Efektivitas Penerapan Sistem E-Faktur Dan Sanksi Perpajakan Terhadap Tingkat Kepatuhan Pengusaha Kena Pajak (Survei Pada Kantor Konsultan Pajak ABC).

Ramli, R. R. (2020, Januari Rabu). 5 Alasan Penerimaan Pajak 2019 Tak Capai Target. Sari, D. (2013). Konsep Dasar Perpajakan. Bandung: PT. Refika Aditama.

Sarunan, W. K. (2015). Pengaruh Modernisasi Sistem Administrasif Perpajakan Terhadap Kepatuhan Wajib Pajak Orang Pribadi Dan Wajib Pajak Badan Pada Kantor Pelayanan Pajak Pratama Manado. Jurnal EMBA Vol.3 No.4, 518-526.

Siti, R. (2014). Perpajakan Teori dan Kasus Edisi 8. Jakarta: Salemba 4.

Sugiyono. (2017). Metode Penelitian Kuantitatif,Kualitatif, dan R\& D. Bandung: Alfabeta. Supadmi, S. d. (2016). Pengaruh Kualitas Pelayanan, Sanksi Perpajakan, Biaya Kepatuhan Pajak, Dan Penerapan E-Filing Pada Kepatuhan Wajib Pajak. E-Jurnal Akuntansi, 1239-1269.

Teguh Hadi Wardoyo, A. S. (2017). Pengantar Perpajakan Indonesia. Tangerang: TaxSys. Waluyo. (2016). Akuntansi Pajak Edisi 6. Jakarta: Salemba Empat. 